\title{
Viral load in upper respiratory tract of COVID-19 patients detected by digital PCR
}

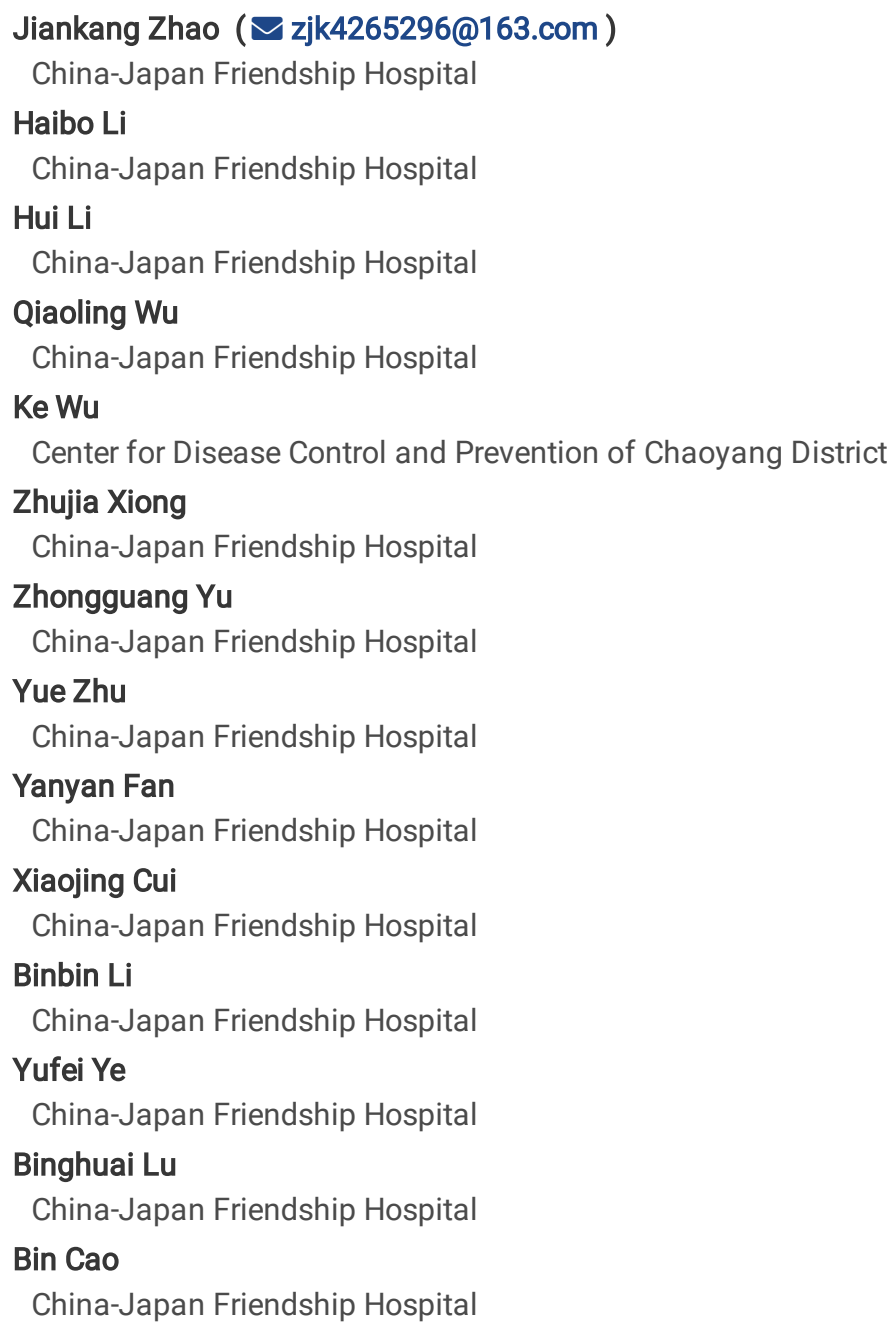

License: @) (i) This work is licensed under a Creative Commons Attribution 4.0 International License. Read Full License 


\section{Abstract}

Background: Upper respiratory tract specimens are widely applicable for the diagnosis of COVID-19. To date, no study has analyzed the actual viral loads in upper respiratory tract and its relationship with the severity of lung lesions, Ct value of RT-PCR and transmission capacity in COVID-19 patients.

Methods: We retrospectively enrolled nine COVID-19 patients. Clinical data and close contacts of these patients were investigated. Respiratory samples were tested for SARS-CoV-2 with both normal RT-PCR and droplet digital PCR.

Results: All the COVID-19 patients complicated with pneumonia. Viral loads in nasopharyngeal swabs were accurately quantified, and they had no direct correspondence with the severity of lung lesions. The Cycle Threshold (Ct) value of RT-PCR was approximately consistent with the absolute quantification of digital PCR. The spearman correlation coefficient between them was -0.952 with $P$ value $<0.001$. Close contacts of patients with very low viral load or no detected virus were not infected.

Conclusions: Viral loads in nasopharyngeal swabs, could not predict the severity of lung lesions revealed by CT in COVID-19 patients. The infectious capacity of patients with low or absent viral load in upper respiratory tract was relatively weak, and wearing mask might be helpful for lower its spread.

\section{Background}

Severe acute respiratory syndrome coronavirus 2 (SARS-CoV-2), first reported in Wuhan city [1], has widely spread worldwide. As of March 9, 2020, more than 100 countries have reported confirmed patients of SARS-CoV-2 infection, and coronavirus disease 19 (COVID-19) has killed at least 3,110 persons. The disease has shown a global pandemic trend, timely diagnosis and effective management are essential to prevent further spread of this coronavirus [2].

SARS-CoV-2 was first identified in bronchoalveolar lavage fluid (BALF) using high-throughput sequencing [3]. Whole genome sequencing (WGS) of this novel coronavirus was deposited on PubMed website shortly after that. Real-time reverse transcriptase-polymerase chain reaction (RT-PCR) detection using specific primers and probe was quickly developed for diagnosis of SARS-CoV-2 infection [4, 5]. The upper respiratory tract samples, including oropharyngeal and nasopharyngeal swabs were recommended for the diagnosis of COVID-19 [6], partly because few patients might produce sputum $[1,7]$. However, more studies argued that lower respiratory tract samples including sputum and BALF might be better sample types for the novel coronavirus detection $[8,9]$. One study showed that a suspected patient was positive for the fifth time after 4 negative detections using RT-PCR with nasopharyngeal swab [10]. Winichakoon, P. and colleagues reported a case of COVID19 pneumonia diagnosed by using BALF with initially negative detection from nasopharyngeal and oropharyngeal swabs [11]. Another study also suggested that some confirmed patients may be RT-PCR negative initially [12]. Such a high negative rate of RT-PCR makes early diagnosis of SARS-CoV-2 infections a huge challenge. Therefore, it is critical to elucidate the cause of the high negative rate RT-PCR.

Droplet digital PCR is a more precise absolute quantitative method with detection limit up to single copy [13]. The reaction solution is divided into thousands of small droplets of water-in-oil, each of which is separately amplified by PCR $[14,15]$. Digital PCR does not depend on calibration curves, endpoint amplification method is used to detect and calculate the number of nucleic acids molecule, which is less subject to enzyme inhibition [16]. In this study, we detected the number of copies of SARS-CoV-2 RNA in different samples using digital PCR, and collected the clinical data, to clarify the actual viral load of the upper respiratory tract samples and its relationship with the severity of lung lesions and transmission capacity of patients infected with SARS-CoV-2.

\section{Methods}

\section{Study design and patients}

All the laboratory-confirmed COVID-19 patients with clinical data available in China-Japan Friendship Hospital from 20 January, 2020 to 9 March, 2020 were enrolled in the study. Their demographic and clinical data were collcected. Droplet digital PCR was also performed to determine the relationship of viral loads of samples and clinical characteristics of patients. This case series was approved by the Ethics Committee of China-Japan Friendship Hospital with approval number 2019-122-K84.

\section{Viral nucleic acid extraction}

Virus inactivation of all samples were conducted with $56^{\circ} \mathrm{C}$ water bath for 30 minutes before nucleic acid extraction. Viral RNAs was extracted from sputum, bronchoalveolar lavage fluid (BALF) and nasopharyngeal swab sampled from patients suspected to be infected by SARS-CoV-2 
using the Viral Total Nucleic Acid Extraction kit (HEAS BioTech, Guangzhou, China) in the SMART32 system (Liferiver, Shanghai, China) following their instruction manuals [17]. A total of $200 \mu \mathrm{l}$ volume of each samples were used for the extraction. The extracted viral nucleic acids were transferred into $1.5 \mathrm{ml}$ Eppendorf tubes and stored at $-20^{\circ} \mathrm{C}$ until use.

\section{Primer and probe sequences}

Primer and probe sequences of ORF1ab and N gene of 2019-nCoV recommended by Chinese Center for Disease Control and Prevention (China $\mathrm{CDC}$ ) was synthesized and checked by Sangon Biotech Company (Shanghai, China). The primer and probe sequences for the ORF1ab gene are: 5'-CCCTGTGGGTTTTACACTTAA-3' (Forward), 5'-ACGATTGTGCATCAGCTGA-3' (Reverse) and 5'-FAM-

CCGTCTGCGGTATGTGGAAAGGTTATGG-BHQ1-3' (Probe), whereas the primer and probe sequences for the $\mathrm{N}$ gene are: $5^{\prime}$ GGGGAACTTCTCCTGCTAGAAT-3' (Forward), 5'-CAGACATTTTGCTCTCAAGCTG-3' (Reverse) and 5'-FAM-TTGCTGCTGCTTGACAGATT-TAMRA3' (Probe).

\section{RT-PCR}

RT-PCR kit for SARS-CoV-2 (DaAn Gene Co., Ltd. of Sun Yat-Sen University, Guangzhou, China) was used. The kit used ORF1ab and N genes of SARS-CoV-2 as the target regions of amplification and fluorescence detection. A total of $25 \mu$ volume of reaction system was prepared for nucleic acid detection, including $17 \mu \mathrm{l}$ reaction solution A (composed of primers, probe and buffer), $3 \mu \mathrm{l}$ reaction solution $\mathrm{B}$ (composed of enzymes mix) and $5 \mu$ l template. Positive and negative control were added to each RT-PCR amplification reaction. RT-PCR assay was run on LightCycler 480 II real- time PCR system (Roche, Basel, Switzerland) with the following reaction conditions: reverse transcription at $50^{\circ} \mathrm{C}$ for 15 min, transcriptase inactivation of reverse at $95^{\circ} \mathrm{C}$ for $15 \mathrm{~min}$, followed by 45 cycles of denaturing at $94^{\circ} \mathrm{C}$ for $15 \mathrm{~s}$ and annealing/extending at $55^{\circ} \mathrm{C}$ for $45 \mathrm{~s}$ ). The total run time for RT-PCR was about $1 \mathrm{~h}$ and $35 \mathrm{~min}$. Interpretation of the results was performed according to the manufacturer's instruction.

\section{Droplet digital PCR}

Droplet digital PCR was conducted using the QX200 Droplet Digital PCR system (BIO-RAD, Hercules, USA) to determine the viral loads of upper or lower respiratory tract samples of SARS-CoV-2 infected patients. One-Step RT-ddPCR Advanced Kit for Probes (BIO-RAD, Hercules, USA) was used for amplify the target gene. Briefly, a total of $20 \mu$ l of reaction solutions (including $5 \mu$ supermix, $2 \mu$ reverse transcriptase, 15 mM DTT, $900 \mathrm{nM}$ forward and reverse primers, $250 \mathrm{nM}$ probe, $5 \mu$ template and supplemented sterile RNase-/DNase-free water to $20 \mu \mathrm{l}$ volume) was prepared and then covered with oil. Bio-Rad QX200 Droplet Generator was used to produce droplets, which were transferred to a 96-well PCR plate for RT-PCR amplification following the reaction conditions: reverse transcription at $45^{\circ} \mathrm{C}$ for 60 min, enzyme activation at $95^{\circ} \mathrm{C}$ for 10 min, 40 cycles of denaturation at $95^{\circ} \mathrm{C}$ for $30 \mathrm{~s}$ and annealing/extension at $58^{\circ} \mathrm{C}$ for $1 \mathrm{~min}$, followed by enzyme deactivation at $98^{\circ} \mathrm{C}$ for 10 min and hold at $4{ }^{\circ} \mathrm{C}$. Fluorescence signal of each droplet was subsequently read and analyzed using Bio-Rad OX200 Droplet Reader [17]. Primers and probe of $\mathrm{N}$ gene of SARS-CoV-2 were selected for SARS-CoV-2 detection in the digital PCR assay. Sterilized deionized distilled water was added to reaction system as negative control. The number of copies per reaction was converted to copies per milliliter of the original sample [13].

\section{Statistical analysis}

Spearman correlation analysis was used for analyzing the correlation between Ct value of RT-PCR and copy number of digital PCR using SPSS Statistics version 21 (IBM).

\section{Results}

Patients enrolled in this study All the nine patients tested positive for SARS-CoV-2 in China-Japan Friendship Hospital from 20 January, 2020 to 9 March, 2020 were enrolled in this study. The age of these patients ranged from 31 to 69 years old and the time from disease onset to laboratory confirmation with RT-PCR were 1-12 days (Table 1). All the patients complicated with pneumonia, which was characterized by subpleural ground grass opacity in chest CT (Figure 1). Viral loads tested with RT-PCR and droplet digital PCR Digital PCR was conducted to 
perform to verify the results of RT-PCR. As shown in table 1, the Ct value of RT-PCR was consistent with the number of copies of digital PCR. The spearman correlation coefficient between them was -0.952 with $\mathrm{P}$ value $<0.001$. Therefore, the Ct values of upper airway specimens can reflect the actual virul loads. In addition, the Ct values of patient 8 in the two detection channels of ORF1ab and N genes were 36.90 and 40.69 , respectively. According to the manuals of nucleic acid detection kit, Ct value $>40$ can be considered negative, and positive in single channel should be repeated. The second test got the similar result. Digital PCR detection showed that the viral load of this sample was just 88 copies/ml. Therefore, RT-PCR single channel positive should not rule out COVID-19. Viral loads and severit of lung lesions The absolute quantification results had nothing to do with the segments number involved and the severity of lung lesions by CT. For example, as shown in the CT image, the range of lesions in patient 8 was the largest, but the upper airway viral load was only 256 copies/ml. Whereas patient 4 had very few ground glass opacity, but the viral load was as high as 80,800 copies/ml. Patient 6 is a case that we reported before [18]. Three nasopharyngeal swabs and one sputum tests were negative before laboratory comfirmation with sputum and BALF 5 days later (Figure 2a). The digital PCR tests showed that there were no copies of the three nasopharyngeal swabs and one sputum from January 23 , January 24 , and January 30 (Figure 2b). However, the chest radiographs on January 30 showed the most serious lesions (Figure 2c). This suggested that the patient's upper respiratory tract viral load may has little to do with the severity of lung lesions. In contrast, the absolute value of lymphocytes may better reflect the disease status. Patient 8 had the most severe lung lesions compared to the other patients, and the lymphocyte value was the lowest $(0.65 \times 109 / \mathrm{L})$. The absolute value of lymphocytes in patient 7 was lower in the severe stage of lung disease $(0.38 \times 109 / \mathrm{L})$, and relatively higher when the lung was normal $(2.18 \times 109 / \mathrm{L})$. Viral loads and transmission capacity Transmission capacity of SARS-CoV-2 is a commonly concerned issue. There was no data showing the relationship between viral load of SARS-CoV-2 in upper respiratory tract and its transmission capacity. In this study, we surveyed whether patients' close contacts were infected with SARS-CoV-2 and its relationship with viral load in the upper respiratory tract of the index person. All patients, except patient 6 and patient 7, were laboratory confirmed with SARS-CoV-2 infection and transferred to designated infectious disease hospitals on the day of consultation. These patients with lower viral load (< 1,000 copies $/ \mathrm{ml}$ ) including patient 8 and patient 9, or no copy number of SARS-CoV-2 (early stages of patient 6) did not infect other people. Patient 6 had 3 close contacts (Figure 3 ) before coming to the hospital, and 39 medical staffs were exposed under limited protection after admission. All these people had no infection during the isolation period (> 30 days) (Figure 3). Patient 7, who returned to Beijing from a non-SARS-CoV-2epidemic area on January 23 by plane, developed symptoms on January 24 . He was initially diagnosed as influenza rather than COVID-19 in the fever clinic. Before admitted to the hospital, he had two close contact persons, including his wife. The patient's condition worsened on January 30 and was admitted to the general ward and he was confirmed as COVID-19 after 2 days. During this period, 9 doctors and nurses were in close contact under limited protection with surgical mask. The Ct values for SARS-CoV-2 of the initial nasopharyngeal swabs were 34.11 (ORF1ab) and $34.49(\mathrm{~N})$, and the absolute quantification of digital PCR was 1,440 copies/ml. However, his wife was infected with SARSCoV-2.

\section{Discussion}

In this study, we collected clinical data of nine laboratory-confirmed COVID-19 patients with RT-PCR, and used digital PCR to accurately quantify the viral load of their upper respiratory tract specimens. The major object of this study is to clarify the actual viral load of upper respiratory tract specimens and its possible relationship with patients' lung lesions and transmission capacity.

At present, nucleic acid detection of SARS-CoV-2 using RT-PCR is the most applicable method for the diagnosis of suspected cases. Upper respiratory tract samples, especially nasopharyngeal swabs, are widely used due to their easy sampling. However, there have been some reports of false negative in RT-PCR [10-12, 19, 20]. One study enrolled 20 laboratory-confirmed COVID-19 patients, only 17 (70\%) and 3 (15\%) of whom were positive for the first and second RT-PCR test with nasopharyngeal swabs, respectively [21]. In our study, one patient was negative for the first 3 times of nucleic acid detection with nasopharyngeal swabs, and positive with BALF 5 days later. Several factors may contribute to the false negative results, among which sampling sites is an important one. SARS-CoV-2 mainly causes lung disease [1], sampling in the upper respiratory tract at the early stage of infection may lead to negative result [22], which was consistent with the observations of higher viral loads in lower respiratory tract samples of MERS-CoV infected patients [23]. We initially suspected that the sensitivity of RT-PCR was part of the reasons for negative detection, therefore a more precise digital PCR was performed to absolute quantify the virus content in the nasopharyngeal swabs with negative RT-PCR results, but our experimental results rejected the above guess. The Ct values of RT-PCR and copy number of digital PCR were highly consistent. Our study is limited by the small sample size, therefore, the conclusions should be interpreted with caution and futher study should be conducted in future.

Whether the viral load of SARS-CoV-2 in upper respiratory tract can be correlated with the patient's condition is of great concern. Previous research has shown that ACE2, a receptor for cell entry by SARS-CoV-2 [24], is widely expressed in the epithelial cells of the whole respiratory tract from nose to alveoli [25]. SARS-CoV-2 mainly cause lung diseases, and also SARS-CoV-2 was detected in saliva and nasopharyngeal swabs [26]. However, there has been no study right now to analyze the link between viral loads in upper respiratory tract and the severity of lung lesions by CT. In our study, we described the extent of lung lesions in COVID-19 patients, and determined the absolute content of viral 
nucleic acid in patients' nasopharyngeal swabs using digital PCR. The results revealed that viral loads in nasopharyngeal swabs could not predict the severity of lung lesions by CT in COVID-19 cases.

In addition, we conducted a brief assessment of the transmission capability of SARS-CoV-2. We found that the nasopharyngeal swab negative patients seemed to have weak infection capacity. The nasopharyngeal swabs of patient 6,8 and 9 were either negative or weakly positive for SARS-CoV-2 (Table 1), and all their close contacts were not infected. This might be because that all people healthcare staff have a certain degree of protection after the outbreak was reported, but it can also be explained by the lower infectious capacity due to the reduced upper respiratory tract viral load [1].

\section{Conclusions}

We evaluated the viral load of upper respiratory tract specimens using digital PCR for the first time. The results showed that RT-PCR was consistent with digital PCR and can well reflect the viral load of upper respiratory tract specimen, especially nasopharyngeal swabs. This study also verified that low viral load indicated relative weak transmission capacity, and the viral load in upper respiratory tract was not associated with the severity of lung lesions by CT in COVID-19 patients. Therefore, considering the limitation of upper respiratory tract specimens, testing lower respiratory specimen maybe better choice for suspected patients.

\section{Availability Of Data And Materials}

The datasets supporting the conclusions of this article are included within the article.

\section{Abbreviations}

\section{SARS-CoV-2}

Severe acute respiratory syndrome coronavirus 2

COVID-19

coronavirus disease 19

BALF

bronchoalveolar lavage fluid

WGS

Whole genome sequencing

RT-PCR

Reverse transcriptase-polymerase chain reaction

\section{Declarations}

\section{Ethical Approval}

This case series was approved by the Ethics Committee of China-Japan Friendship Hospital with approval number 2019-122-K84.

\section{Conflicts of interest}

None

\section{Funding Source}

None

\section{Authors' Contributions}

J.Z. and H.L. designed the research; H.L., Q.W., K.W., Z.X., Z.Y., Y.Z., Y.F., X.C., B.L. and Y.Y. collected the data; J.Z. and H.L. analyzed the data; J.Z wrote the paper; B.L. and B.C. revised the paper; B.C. provided the experimental conditions. All authors approved the final article and are accountable for all aspects of the work. 


\section{Acknowledgements}

We thank all staffs of Laboratory of Clinical Microbiology and Infectious Diseases, China-Japan Friendship Hospital participating in the detection of SARS-CoV-2.

\section{References}

1. Huang C, Wang Y, Li X, Ren L, Zhao J, Hu Y, Zhang L, Fan G, Xu J, Gu X, et al. Clinical features of patients infected with 2019 novel coronavirus in Wuhan, China. The Lancet. 2020;395(10223):497-506.

2. Bassetti M, Vena A, Giacobbe DR. The novel Chinese coronavirus (2019-nCoV) infections: Challenges for fighting the storm. Eur J Clin Invest 2020:e13209.

3. Lu R, Zhao X, Li J, Niu P, Yang B, Wu H, Wang W, Song H, Huang B, Zhu N, et al. Genomic characterisation and epidemiology of 2019 novel coronavirus: implications for virus origins and receptor binding. The Lancet. 2020;395(10224):565-74.

4. Corman VM, Landt O, Kaiser M, Molenkamp R, Meijer A, Chu DK, Bleicker T, Brunink S, Schneider J, Schmidt ML, et al: Detection of 2019 novel coronavirus (2019-nCoV) by real-time RT-PCR. Euro Surveill 2020, 25(3).

5. Chu DKW, Pan Y, Cheng SMS, Hui KPY, Krishnan P, Liu Y, Ng DYM, Wan CKC, Yang P, Wang Q, et al: Molecular Diagnosis of a Novel Coronavirus (2019-nCoV) Causing an Outbreak of Pneumonia. Clin Chem 2020.

6. China National Health Commission: Diagnosis and treatment for the novel coronavirus pneumonia (trial version 5 ). 2020 [cited 8 Feb 2020] http://www.nhc.gov.cn/xcs/zhengcwj/202002/3b09b894ac9b4204a79db5b8912d4440/files/7260301a393845fc87fcf6dd52965ecb.pdf.

7. Guan WJ, Ni ZY, Hu Y, Liang WH, Ou CQ, He JX, Liu L, Shan H, Lei CL, Hui DSC, et al: Clinical Characteristics of Coronavirus Disease 2019 in China. N Engl J Med 2020.

8. To KK, Tsang OT, Chik-Yan Yip C, Chan KH, Wu TC, Chan JMC, Leung WS, Chik TS, Choi CY, Kandamby DH, et al: Consistent detection of 2019 novel coronavirus in saliva. Clin Infect Dis 2020.

9. Yang Y, Yang M, Shen C, Wang F, Yuan i, JinxiuLi, Zhang M, Wang Z, Xing L, Wei J, et al: Evaluating the accuracy of different respiratory specimens in the laboratory diagnosis and monitoring the viral shedding of 2019-nCoV infections. medRxiv 2020.

10. Tay JY, Lim PL, Marimuthu K, Sadarangani SP, Ling LM, Ang BSP, Chan M, Leo YS, Vasoo S. De-isolating COVID-19 Suspect Cases: A Continuing Challenge. Clin Infect Dis 2020.

11. Winichakoon P, Chaiwarith R, Liwsrisakun C, Salee P, Goonna A, Limsukon A, Kaewpoowat Q. Negative Nasopharyngeal and Oropharyngeal Swab Does Not Rule Out COVID-19. J Clin Microbio/ 2020.

12. Xie X, Zhong Z, Zhao W, Zheng C, Wang F, Liu J. Chest CT for Typical 2019-nCoV Pneumonia: Relationship to Negative RT-PCR Testing Radiology 2020.

13. Chan KH, Hijano DR, Brazelton de Cardenas J, Maron G, Garner CD, Ferrolino JA, Dallas RH, Gu Z, Hayden RT. Clinical correlation of influenza and respiratory syncytial virus load measured by digital PCR. PloS one 2019, 14(9).

14. Hayden RT, Gu Z, Ingersoll J, Abdul-Ali D, Shi L, Pounds S, Caliendo AM. Comparison of droplet digital PCR to real-time PCR for quantitative detection of cytomegalovirus. J Clin Microbiol. 2013;51(2):540-6.

15. Huggett JF, Cowen S, Foy CA. Considerations for digital PCR as an accurate molecular diagnostic tool. Clin Chem. 2015;61(1):79-88

16. Zhang K, Lin G, Li J. Quantitative nucleic acid amplification by digital PCR for clinical viral diagnostics. Clin Chem Lab Med. 2016;54(9):1427-33.

17. Zou X, Chang K, Wang Y, Li M, Zhang W, Wang C, Lu B, Xiong Z, Han J, Zhang Y, et al. Comparison of the Cepheid Xpert Xpress Flu/RSV assay and commercial real-time PCR for the detection of influenza A and influenza B in a prospective cohort from China. Int $\mathrm{J}$ Infect Dis. 2019;80:92-7.

18. Xiaojing W, Ying C, Xu H, Xin Y, Li Z, Fan W, Quanguo L, Sichao G, Teng X, Yongjun L, et al: Co-infection with SARS-CoV-2 and Influenza A Virus in Patient with Pneumonia, China. Emerging Infectious Disease journal 2020, 26(6).

19. Bai Y, Yao L, Wei T, Tian F, Jin DY, Chen L, Wang M: Presumed Asymptomatic Carrier Transmission of COVID-19. JAMA 2020.

20. Sun X, Zhang X, Chen X, Chen L, Deng C, Zou X, Liu W, Yu H: The infection evidence of SARS-COV-2 in ocular surface: a single-center cross-sectional study. medRxiv 2020.

21. Ai JW, Zhang HC, Xu T, Wu J, Zhu MQ, Yu Y-Q, Zhang H-Y, Shen Z, Li Y, Zhou X, et al: Optimizing diagnostic strategy for novel coronavirus pneumonia, a multi-center study in Eastern China. medRxiv 2020.

22. Li Z, Yi Y, Luo X, Xiong N, Liu Y, Li S, Sun R, Wang Y, Hu B, Chen W, et al: Development and Clinical Application of A Rapid IgM-IgG Combined Antibody Test for SARS-CoV-2 Infection Diagnosis. J Med Virol 2020.

Page 6/10 
23. Memish ZA, Al-Tawfiq JA, Makhdoom HQ, Assiri A, Alhakeem RF, Albarrak A, Alsubaie S, Al-Rabeeah AA, Hajomar WH, Hussain R, et al. Respiratory tract samples, viral load, and genome fraction yield in patients with Middle East respiratory syndrome. $J$ Infect Dis.

2014;210(10):1590-4.

24. Zhou P, Yang XL, Wang XG, Hu B, Zhang L, Zhang W, Si HR, Zhu Y, Li B, Huang CL, et al: A pneumonia outbreak associated with a new coronavirus of probable bat origin. Nature 2020.

25. Hamming I, Timens W, Bulthuis MLC, Lely AT, Navis GJ, van Goor H. Tissue distribution of ACE2 protein, the functional receptor for SARS coronavirus. A first step in understanding SARS pathogenesis. J Pathol. 2004;203(2):631-7.

26. To KK-W, Tsang OT-Y, Chik-Yan Yip C, Chan K-H, Wu T-C, Chan JMC, Leung W-S, Chik TS-H, Choi CY-C, Kandamby DH, et al: Consistent detection of 2019 novel coronavirus in saliva. Clin Infect Dis 2020:ciaa149.

\section{Tables}

Table 1. Clinical features and nucleic acid content in upper respiratory tract specimens of COVID-19 patients

\begin{tabular}{|c|c|c|c|c|c|c|c|c|c|c|c|c|}
\hline Patient & Age & Gender & Time to onset(day) & Cough & Sputum & Dyspnea & Fever & Lymphocyte $\left(10^{9} / \mathrm{L}\right)$ & $\begin{array}{l}\text { Target } \\
\text { gene }\end{array}$ & Ct value & Copy $/ \mathrm{mL}$ & Segments \\
\hline \multirow[t]{2}{*}{1} & 47 & male & 2 & no & no & yes & yes & 2.36 & ORF1ab & 30.95 & 12,080 & 1 \\
\hline & & & & & & & & & $\mathrm{N}$ & 31.84 & & \\
\hline \multirow[t]{2}{*}{2} & 35 & male & 6 & no & no & no & yes & 2.18 & ORF1ab & 31.76 & 4,960 & 4 \\
\hline & & & & & & & & & $\mathrm{N}$ & 31.6 & & \\
\hline \multirow[t]{2}{*}{3} & 51 & female & 6 & no & no & no & yes & 0.96 & ORF1ab & 30.67 & 10,720 & 7 \\
\hline & & & & & & & & & $\mathrm{N}$ & 30.80 & & \\
\hline \multirow[t]{2}{*}{4} & 59 & male & 3 & yes & No & no & yes & 1.01 & ORF1ab & 27.85 & 80,800 & 1 \\
\hline & & & & & & & & & $\mathrm{N}$ & 26.62 & & \\
\hline \multirow[t]{2}{*}{5} & 56 & female & 8 & yes & no & yes & yes & 1.03 & ORF1ab & 28.48 & 14,960 & 1 \\
\hline & & & & & & & & & $\mathrm{N}$ & 28.79 & & \\
\hline 6 & 61 & male & 7 & no & no & no & yes & 0.67 & ORF1ab & 34.11 & 1,440 & 1 \\
\hline $\mathrm{N}$ & 34.49 & & & & & & & & & & & \\
\hline \multirow[t]{2}{*}{7} & 68 & male & 9 & yes & no & no & yes & 0.65 & ORF1ab & 37.43 & 256 & 3 \\
\hline & & & & & & & & & $\mathrm{N}$ & 36.75 & & \\
\hline \multirow[t]{2}{*}{8} & 32 & male & 10 & no & no & no & yes & 1.42 & ORF1ab & 36.90 & 88 & 5 \\
\hline & & & & & & & & & $\mathrm{N}$ & 40.69 & & \\
\hline
\end{tabular}

\section{Figures}



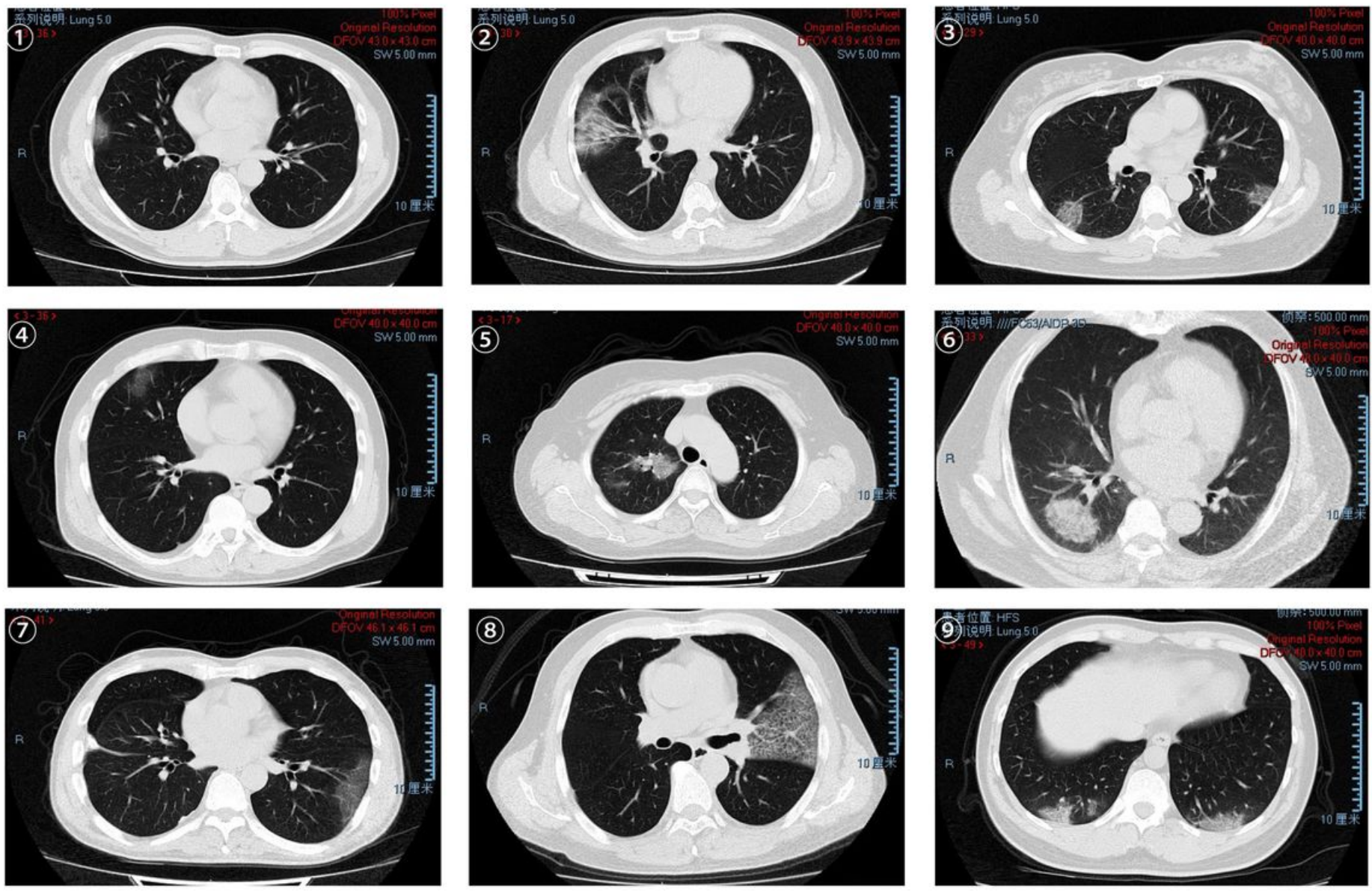

Figure 1

CT images of patient's first visit. 
a)

patient 6

\begin{tabular}{|c|c|c|c|c|}
\hline $23 / 1$ & $24 / 1$ & $30 / 1$ & $4 / 2$ & 5/2 Confirmed \\
\hline Onset I & 1 & 1 & 1 & 1 \\
\hline nasal swab & nasal swab & nasal swab\&sputum & BALF & BALF\& sputum \\
\hline RT-PCR negative & RT-PCR negative & RT-PCR negative & mNGS COVID-19 & RT-PCR positive \\
\hline
\end{tabular}

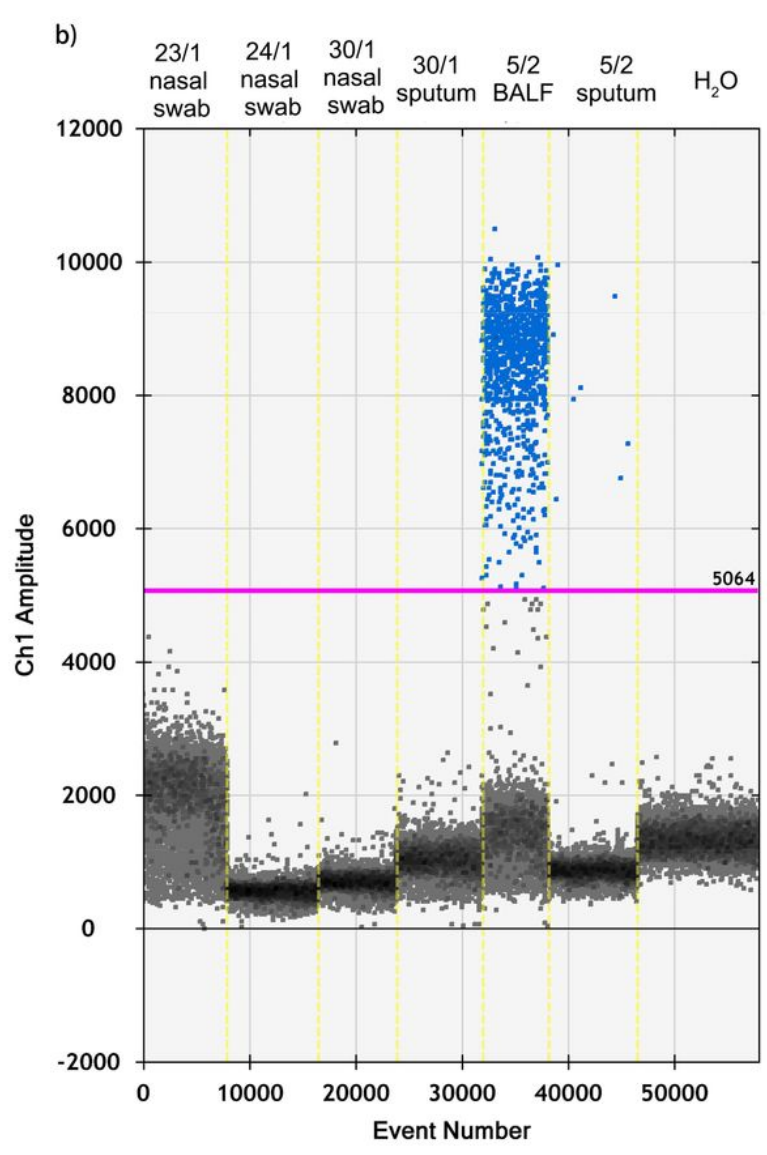

c)
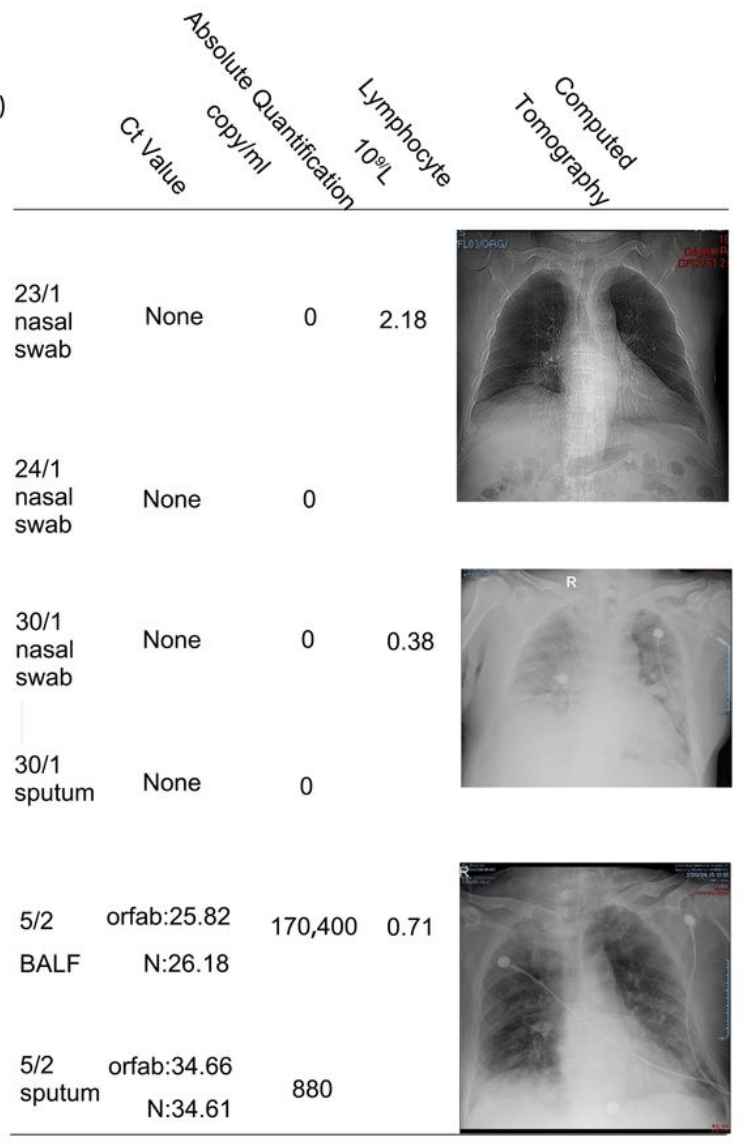

\section{Figure 2}

CT test and viral RNA test results using RT-PCR and digital PCR of patient 6. a) Patient's diagnosis history and RT-PCR test flow chart. b) Result of droplet digital PCR test. c) Absolute quantification and corresponding lymphocytes and chest radiographs. 
blue word:close contact number

red word:comfirmed number return to Beijing or contact to confirmed

admission to hospital

onset

COVID-19 confirmed and transfer to infection hospitol

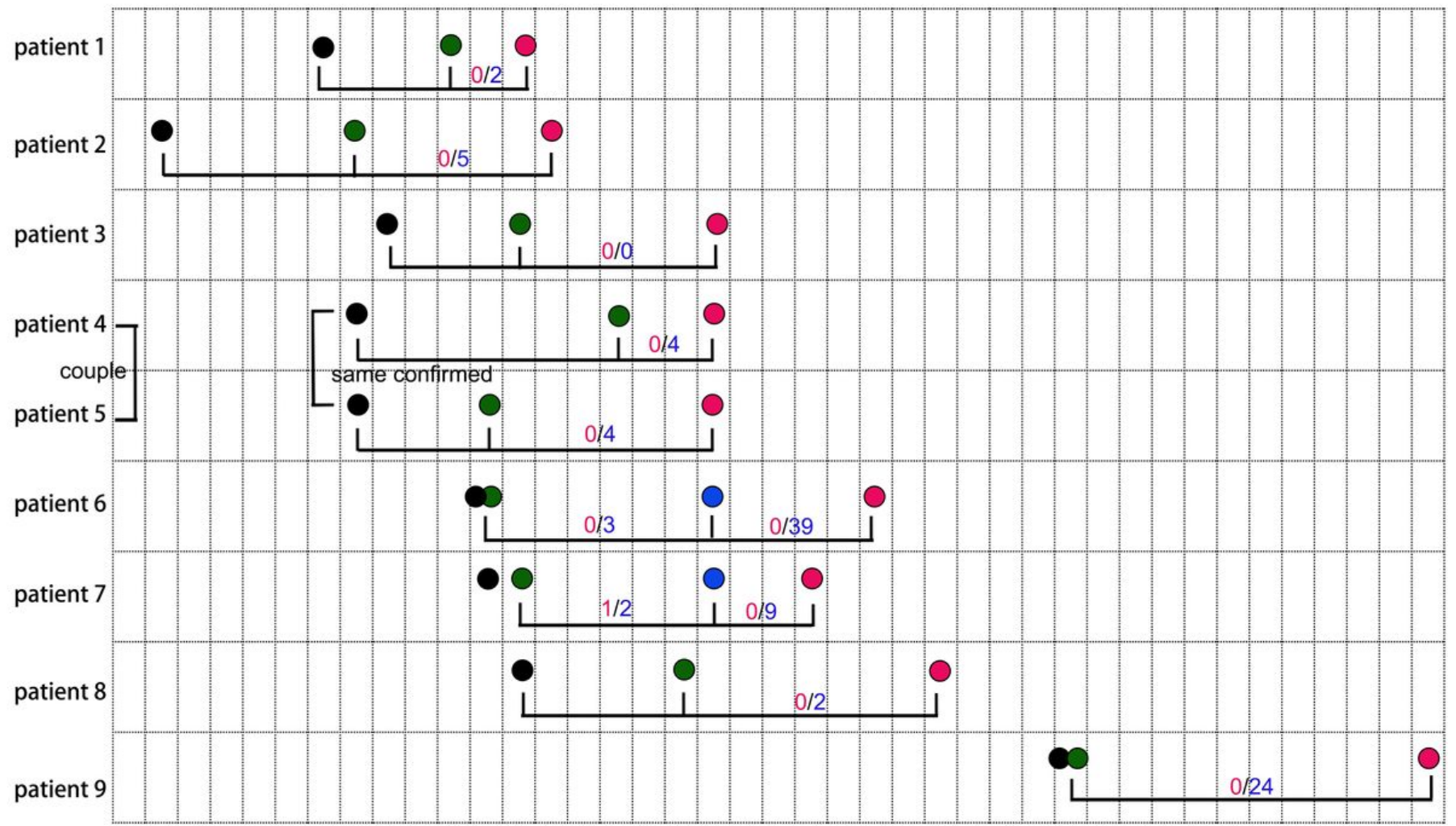

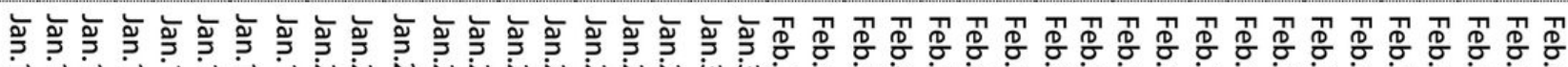

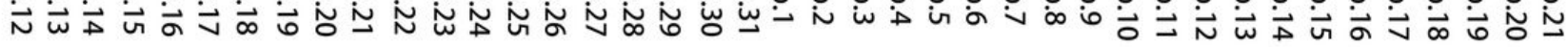

\section{Figure 3}

Close contact history of these 9 COVID-19 patients. 